\title{
Barbara Allen-Diaz: A career applying research to solve California's problems
}

After more than 4 years as the leader of UC Agriculture and Natural Resources, Barbara Allen-Diaz is retiring June 30. Ann Senuta, UC ANR Director of Publishing, provides this retrospective on her career.

\begin{abstract}
ven while she works intensely to tie up her last projects at UC, Barbara Allen-Diaz's career is unspooling behind her in accolades and memories. She retires this month as UC ANR vice president, director of the UC Agricultural Experiment Station, director of UC ANR Cooperative Extension and Russell Rustici Chair in Rangeland Management at UC Berkeley. More broadly, she retires from a 37-year career of improving range science and the environment, mentoring future scientists and shaping a unique component of the UC system.
\end{abstract}

Allen-Diaz grew up in the Pacific Northwest, encouraged by her parents to love the outdoors and know the importance of education. They were practical people - she was accepted to Stanford University, Smith College and the University of Washington, but only the last offered a scholarship, so that is where she went.

Her introduction to UC came at age 20, when she transferred to UC Berkeley, where her new husband

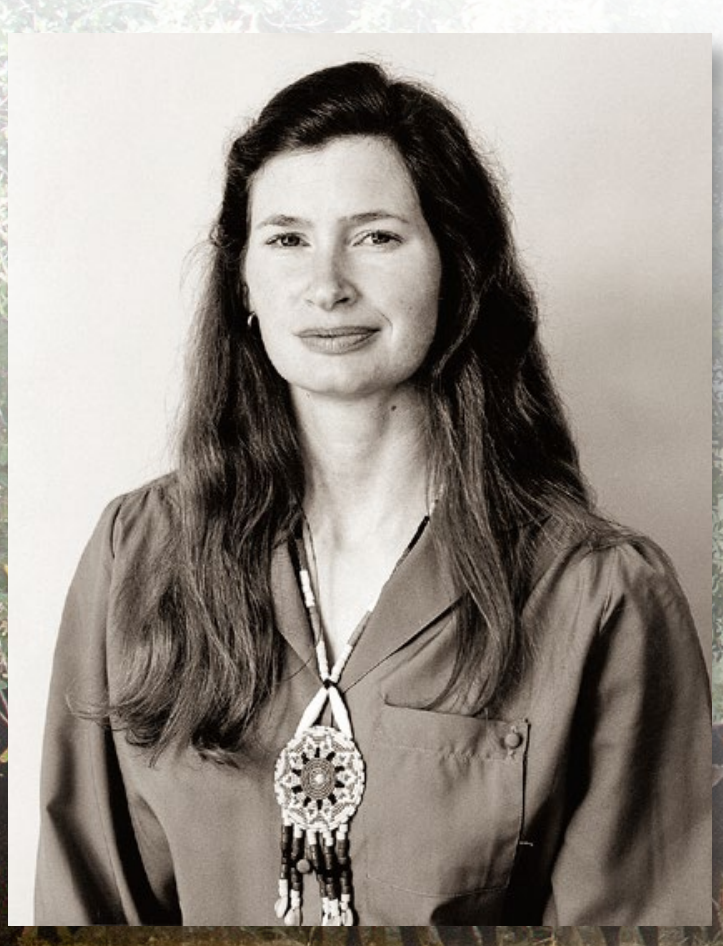

had been accepted to graduate school. "It was not a great decision," she says, because she had only two quarters left to graduate from UW; her double major of biology and human evolution was reduced at UC Berkeley to one - physical anthropology - and she lost her UW scholarship.

Berkeley was expensive, even then, and a culture shock. Frugal times and the breakup of her marriage led Allen-Diaz to reckon with another challenge, her career. "What I was looking for - it was the 1970s - was to help save the world. To help save the world, whatever that meant, as an applied ecologist," she says.

An opportunity arrived via Harold Heady, the associate dean of student affairs at UC Berkeley's College of Natural Resources, who told Allen-Diaz to think about range management. Overnight she considered it, seeing the subject as offering a better understanding of how ecosystems function to enable ecologically sustainable production of goods and services off the land. "The next day, Harold handed me a paper and said to enroll in these classes, and I was in grad school," Allen-Diaz recalls. "He did not say, 'Go away and take the GREs.' He believed in me and took a risk on me."

Allen-Diaz has replicated this support to graduate students throughout her career. "Too many times as professors we don't take a risk on students. But since someone did it for me, I think it is really

Allen-Diaz and Gidget explored Sierra Nevada conifer forests and oak woodlands for her research.

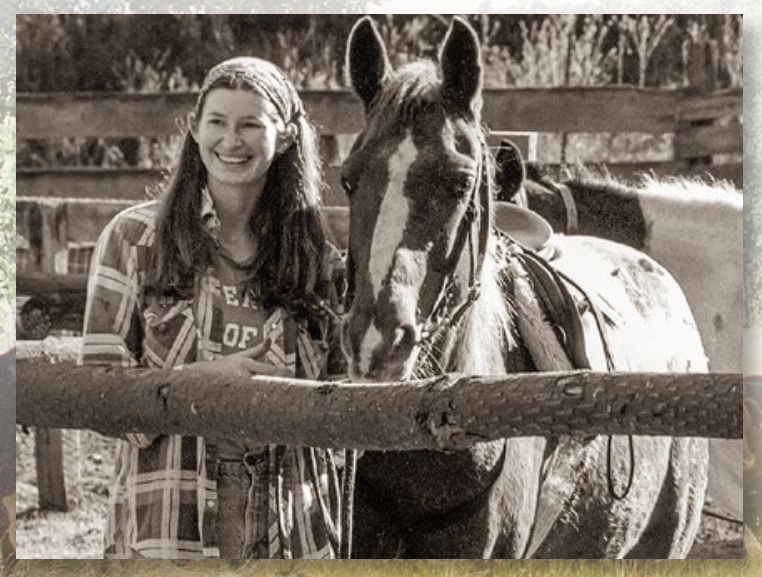


important. And I have had some of the most incredible graduate students that you can imagine."

Allen-Diaz was invited to work with new UC Berkeley researcher James Bartolome, now a Professor of Environmental Science, Policy and Management, as his first graduate student at UC's Blodgett Forest Research Station in El Dorado County. The forest there, a study site for timber management, could not be sprayed aerially with herbicide after a 1977 ruling. Allen-Diaz and Bartolome looked at the feasibility of livestock grazing as an alternative way to reduce unwanted vegetation. They found that cattle would eat the vegetation, including deer brush, which

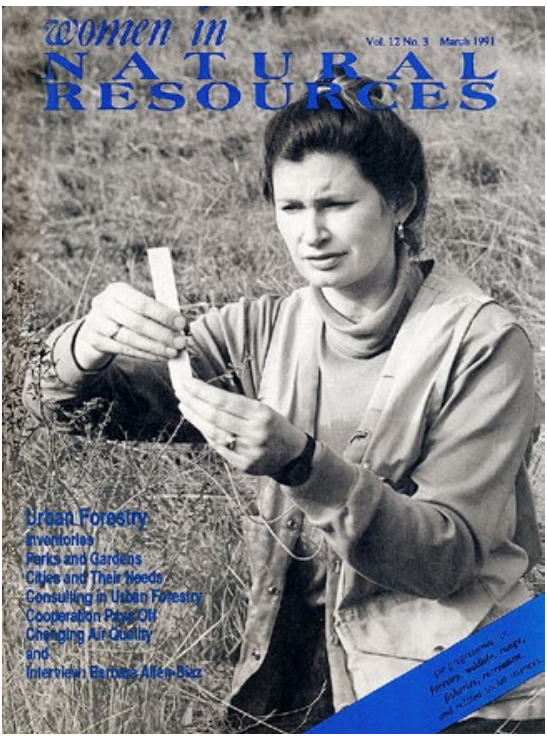

Allen-Diaz appeared on the cover of Women in Natural Resources in 1991. is a palatable, nutritious species that when left to grow reduces forest space and shades young trees.

"We did a lot of research about what species the cows were actually eating, the nutritional value of those species, and what was happening with the meadows," she recalls. Instead of finding overgrazed meadows, they discovered the potential of integrating cattle into a land management regime. Overgrazing could be avoided, they found, "as long as you thought about where you are logging, where you are reforesting, and how livestock are going to be used to help manage tree plantations," Allen-Diaz says. The work led to their first paper together, "Grazing Mixed Conifer Forests," published in California Agriculture in 1978.

Allen-Diaz earned a master's degree in range management that year and a doctorate in wildland resource science in 1980. She hoped to continue her research career as a university faculty member. But after a fruitless academic job search, she instead took a position with the U.S. Forest Service, launching an ecology research program out of the agency's Pacific Southwest Region office in San Francisco. There, Allen-Diaz says, she developed skills that would later serve her well as a university administrator, including "understanding people" and learning how to be effective within a large bureaucracy. The Forest Service also gave her the opportunity to continue her research, working in mountain meadows and oak woodlands, often with her horse, Gidget.
One day in the offices of the Cleveland National Forest in San Diego, Allen-Diaz met her current husband David Diaz, then a Forest Service botanist. They married in 1986, and that same year, Allen-Diaz returned to Berkeley as an assistant professor in the College of Natural Resources, the first woman in the country hired to a tenuretrack position in range science.

Two key findings of AllenDiaz's research were that cattle are not the primary source of excess nitrates in Sierra Nevada spring ecosystems or the main cause of declines in toad populations in the Sierra Nevada, as was widely thought at the time. These findings were important to ranchers, and Allen-Diaz became adept at giving talks at field days and interacting with ranchers at UC ANR Research and Extension Centers (RECs). Lake County rancher Russell Rustici, who later became a major benefactor to UC's range science programs, was often in the audience at her early field talks at the Sierra Foothill and Hopland RECs. Rustici developed a passion for range science and later told Allen-Diaz that her talks inspired him to will much of his estate to the university. In 2005, UC Berkeley named Allen-Diaz the first Russell Rustici Chair in Rangeland Management.

As she rose in the university, Allen-Diaz continued to be a leader in applied research on the management of rangelands and forests. This often meant stepping into controversy. She points to one example in particular, when she and several UC colleagues were asked to review, in just 5 weeks, the science in the Sierra Nevada Ecosystem Project study, a mammoth, multi-agency document intended to guide management decisions on public lands throughout the range.

Allen-Diaz and her team were broadly critical of the study. "In tracing statements back to their original source, we found a tendency to extend research results far beyond their original findings," reads their assessment. One example that Allen-Diaz is fond of citing: A key piece of evidence used to support the conclusion that grazing hurts amphibians was a 1958 laboratory

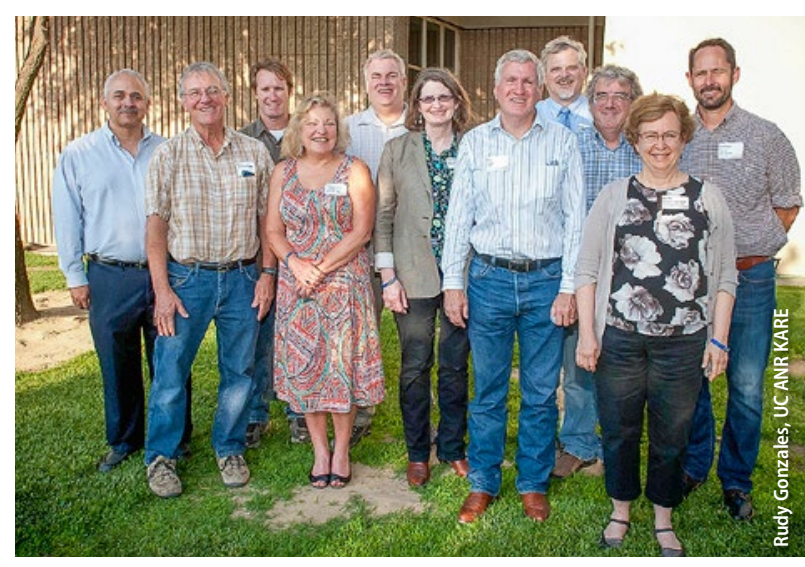

Barbara Allen-Diaz with fellow UC ANR senior administrators and Research and Extension Center directors at Kearney Agricultural Center's recent 50-year anniversary celebration. 
study of salamanders, which found that, when deprived of water and exposed to light, the amphibians died fairly quickly. Over time, says Allen-Diaz, that study "got translated on up the chain into 'livestock are the primary cause of the decline in salamanders in the Sierra Nevada."'

\section{Allen-Diaz's Career Highlights}

\section{UC ANR Leadership}

- Vice President of UC Agriculture and Natural Resources (ANR), Director of the Agricultural Experiment Station and Director of Cooperative Extension in California (2011-2015)

- UC ANR Associate Vice President for Programs and Strategic Initiatives (2009)

- UC ANR Associate Vice President of the Research and Extension Center system (2007)

- Purchased the UC ANR building in east Davis and consolidated more than 145 staff from six buildings in and around the UC Davis campus into one building

- Hired 90 new Cooperative Extension academics to begin rebuilding the UCCE footprint across the state

- Restored UC ANR's direct reporting line to the UC President

- Established two UC ANR institutes, the California Institute for Water Resources and the Nutrition Policy Institute

- Located two UCCE specialists on the UC Merced campus

- Raised external commodity salary support for six UCCE advisor and specialist positions

- Raised money for two endowed Cooperative Extension Chairs for UC ANR

\section{UC Berkeley Faculty Member}

- UC Berkeley faculty member since 1986; retiring as Russell Rustici Chair in Rangeland Management, Department of Environmental Science, Policy and Management

- Associate Dean, Executive Associate Dean and Acting Dean, College of Natural Resources, UC Berkeley (2000-2005)

- Division Head, Ecosystem Sciences, UC Berkeley (1994-1996)

- Chair, Department of Environmental Science, Policy and Management, UC Berkeley (1996)

- Society for Range Management Frederick G. Renner Award for lifetime achievement (first female SRM member to receive the award in the society's 68-year history), 2015

- Society for Range Management Outstanding Achievement Award (2001)

- Society for Range Management California Chapter, Range Manager of the Year (2002)

- Shared in the Nobel Peace Prize awarded to the Intergovernmental Panel on Climate Change (2007)

- Author of more than 170 peer-reviewed articles
She cites her "two-sided personality" — researcher and administrator - for driving her to pursue new leadership challenges. She was appointed associate vice president of the UC ANR REC system in 2007 and associate vice president for UC ANR programs and strategic initiatives in 2009. Two years later, she became vice president of UC ANR, where she has worked to reposition the division as a proactive, high-achieving research and educational arm of UC, and to expand the division's footprint to better serve California's communities and sustain its ecosystems.

Author of more than 170 peer-reviewed papers, Allen-Diaz still values the journal in which she got her start. "California Agriculture is an incredible peerreviewed journal for applied research and communicating why people should care about the research," she says. Applied research that solves problems is the strength of UC ANR and a value Allen-Diaz has championed as its vice president: "It is so important in our fields of agriculture, natural resources, nutrition and youth development. I say to people, this is why they should support their universities."

After retirement she will be taking this idea further in a book she plans to write about higher education. But first she and David will build a writing room on their property in central Oregon, clearing some new ground for Allen-Diaz to continue her lifelong love of learning and the land. CA

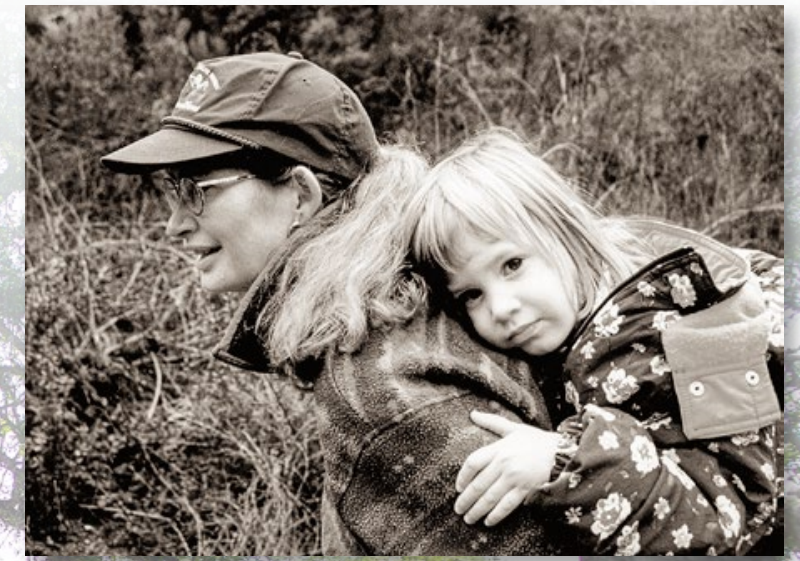

Allen-Diaz introduced her daughter Tianna to the mountains at a young age.

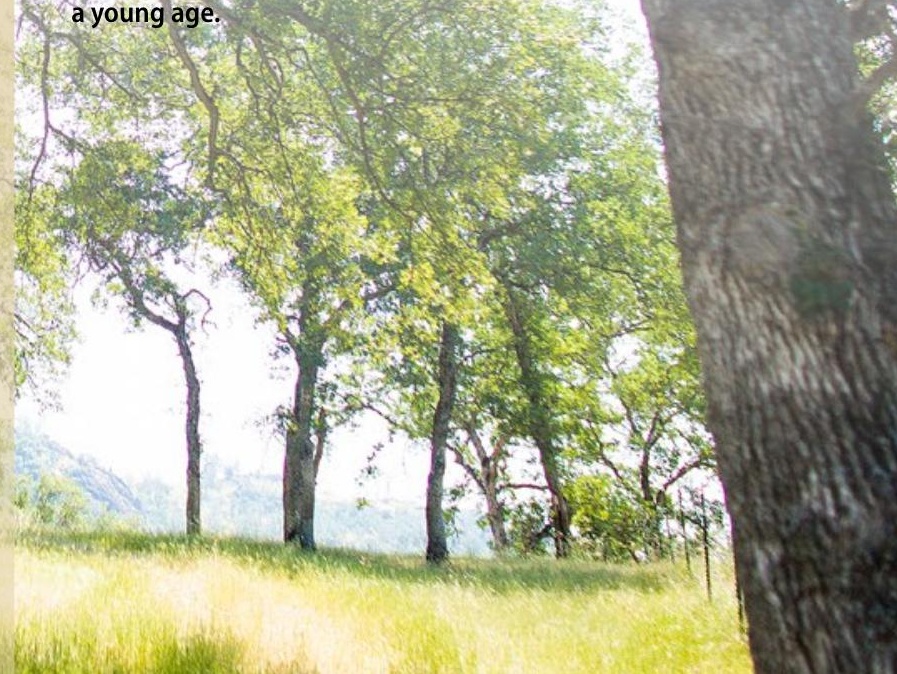

